\title{
Antioxidant Potential and Tyrosinase Inhibitory Properties of Quebecol as Natural Phenolic Compound
}

\section{Parham TASLIMI ${ }^{1 *}$}

\begin{abstract}
In this paper, we investigated the antioxidant potential of Quebecol in vitro using several assays. These; $\mathrm{Cu}^{2+}-\mathrm{Cu}^{+}$reducing, DPPH scavenging, $\mathrm{Fe}^{3+}-\mathrm{Fe}^{2+}$ reducing, $\mathrm{ABTS}^{\cdot+}$ scavenging. The $\mathrm{IC}_{50}$ amounts of the Quebecol in the $\mathrm{DPPH}^{*}$ and $\mathrm{ABTS}^{\cdot+}$ methods were 14.78 and $5.38 \mu \mathrm{g} \mathrm{m}^{1}$, respectively. Tyrosinase enzyme is a functional oxidase that is extensively divided in nature. It is the main enzyme in melanin synthesis and also is involved in designating the color of mammalian hair and skin. Recently, there has been a remarkable concern to study the inhibitory activity of the tyrosinase enzyme and some inhibitory molecules isolated from natural sources. For tyrosinase enzyme, Quebecol and kojic Acid (Standard) as natural phenols have $\mathrm{IC}_{50}$ values of 4.64 and $9.28 \mu \mathrm{M}$.
\end{abstract}

Key words: Quebecol, antioxidant activity, tyrosinase, enzyme inhibition,

\section{Doğal Fenolik Bileşik Olarak Quebecol'un Antioksidan Potansiyeli ve Tirozinaz Inhibitör Özellikleri}

ÖZET: Yapılan bu çalışmada, Quebecol'un in vitro antioksidan özelliklerini farklı testler kullanarak araştırıldı. Bunlar; $\mathrm{Cu}^{2+}-\mathrm{Cu}^{+}$indirgenme, $\mathrm{DPPH}^{\bullet}$ radikal giderme, $\mathrm{Fe}^{3+}-\mathrm{Fe}^{2+}$ indirgenme, $\mathrm{ABTS}^{\cdot+}$ radikal giderme. $\mathrm{DPPH}^{\bullet}$ ve $\mathrm{ABTS}^{\circ+}$ testlerindeki Quebecol'un $\mathrm{IC}_{50}$ değerleri sirasıyla 14.78 ve $5.38 \mu \mathrm{g} \mathrm{mL}^{-1}$ elde edildi. Tirozinaz enzimi, doğada yaygın olarak bulunan fonksiyonel bir oksidazdır. Melanin sentezindeki ana enzimdir ve bu enzim aynı zamanda memeli kıllarının ve cildinin renginin belirlenmesinde önemli rol oynar. Son zamanlarda, tirozinaz enziminin ve bu enzimin doğal kaynaklardan izole edilen bazı inhibitör moleküllerin, aktivitesini incelemek için fazla çalışma bulunmamaktadır. Son zamanlarda, tirozinaz enziminin ve doğal kaynaklardan izole edilen bazı inhibitör moleküllerin inhibitör aktivitesini incelemek çok öneme sahiptir. Tirozinaz enzimi için, doğal fenoller olarak Quebecol ve kojik Asit (Standart), 4.64 ve 9.28 uM'lik IC 50 değerlerine sahiptir.

Anahtar Kelimeler: Quebecol; antioksidan aktivite; tirozinaz; enzim inhibisyonu 


\section{INTRODUCTION}

Recently, increasing concerns about food and nutrition have led to research efforts by the food and university industries to find new bioactive agents that are active in the human diet (Gülçin et al., 2005a). In addition, many of the foods used traditionally and familiarly with a molecular approach, such as foods, have been traded in Canadian handicrafts (especially in the province of Quebec) and maple syrup (Li and seeram, 2011; Ball, 2007). Lee and Siram have just recorded a new polyphenolic (Figure 1). The partridge is named. Natural phenolic compounds are naturally present, and the plant's secondary metabolites are present in almost all plant materials, such as plant-based foods. These compounds appear to be a complete part of the human and animal diets (Elmastaş et al., 2005; Gülçin et al., 2005b).

Nutritional tissues live (or have existed), and are also produced under constant oxidative stress from reactive oxygen species, free radicals, and peroxides as exogenous (light and heat) and endogenous (transport metals and $\mathrm{H}_{2} \mathrm{O}_{2}$ ). In fact, many of these tissues have developed antioxidant systems to control lipid oxidation catalysts, free radicals, secondary decomposition products, and oxidation mediators. Antioxidant molecules such as phenolic acids, carotenoids, flavonoids, and tocopherols, which can inhibit $\mathrm{Fe}^{3+} / \mathrm{AA}$ oxidation, clear free radicals and act as reducing agents (Gülçin et al., 2005c; Gülçin, 2005).



Figure 1. Structure of Quebecol compound

Melanogenesis is a physiological mechanism that leads to the production of melanin pigment, which plays an important role in preventing sunburn. However, the production of melanin in human skin is a major mechanism of light protection against ultraviolet light. Excessive return of epidermal pigments can cause a variety of high blood pressure disorders, such as age spots, melasma, and locations. Be actinic damage (Espin and Wichers, 1999; Mastumoto et al., 2018). As a copper enzyme, tyrosinase catalyzes two separate reactions waiting for melanin biosynthesis, L-tyrosine molecule hydroxylation to L-dopa, and oxidation of the L-dopa molecule to dopukinone, which is highly reactive and can also be automatically converted to melanin. Be. Therefore, regulating melanin synthesis by inhibiting tyrosinase is a common study topic in preventing high blood pressure (Zolghadri et al., 2019; Tanaka et al., 2019).

In this study, we have investigated the in vitro inhibition effects of Quebecol and kojic Acid (as Standard) as natural phenol on tyrosinase enzyme. The significant target of this paper, is compared its antioxidant activity to related standard molecules including BHT, BHA, trolox and $\alpha$-tocopherol (for antioxidant activities). 


\section{MATERIALS AND METHODS}

\section{Antioxidant methods}

\section{$\mathrm{Fe}^{3+}$ reducing}

To assess the ability of $\mathrm{Fe}_{3}$ to reduce the composition of the partridge, the method of reducing $\mathrm{Fe}^{3+}\left(\mathrm{CN}^{-}\right)_{6}$ to $\mathrm{Fe}^{2+}\left(\mathrm{CN}^{-}\right)_{6}$ was utilized and also performed according to former studies (Gülçin et al., 2006a; Gülçin, 2006). According to the results, when the reduction ability decreases, the absorption of more values shows.

\section{Cupric ions $\left(\mathrm{Cu}^{2+}\right)$}

Mineral ions $\left(\mathrm{Cu}_{2}\right)$, which use the power measurement method, have been used as the second way to reduce the ability of cobblestones to combine. The ability to reduce $\mathrm{Cu}_{2}$ was done conforming to the assay explained by Apak et al. (Apak et al., 2007) With low modifications and in accordance with previous studies (Gülçin, 2006; Elmastaş et al., 2006). Sampling was determined at $450 \mathrm{~nm}$ in $30 \mathrm{~min}$.

\section{DPPH` scavenging activity}

DPPH inhibitory activity was determined from the composition of the particle as described earlier. Finally, the absorption amount was determined at $517 \mathrm{~nm}$ in the spectroscopy (Gülçin et al., 2006b).

\section{ABTS $^{\bullet+}$ assay}

ABTS radical cation was generated by the interaction of ABTS $\left(7 \mathrm{mML}^{-1}\right)$ and $\mathrm{K}_{2} \mathrm{~S}_{2} \mathrm{O}_{8}(2.45$ $\mathrm{mML}^{-1}$ ) [85] described previously [86,87]. This solution was diluted with methanol until the absorbance in the samples reached $0.750-0.05$ at $734 \mathrm{~nm}$. Then, $1 \mathrm{~mL}$ of ABTS ${ }^{\bullet}$ solution was supplemented to 3 $\mathrm{mL}$ of novel symmetric sulfamides and control solutions. The extent of decolorization is calculated as a percentage reduction of absorbance. ABTS radical inhibition activity from the composition of the particle utilizing the spectroscopic method described by Re et al. (Re et al., 1999) and was performed according to previous studies.

\section{Tyrosinase enzyme activity}

The inhibitory activity of the natural compound against tyrosinase was studied (Ishioka et al., 2019; Ros et al., 1993). The produced dopacrum values were determined by measuring the absorption rate at $475 \mathrm{~nm}$ using the VersaMaxTM display microplate (molecular devices, USA). Kojic acid (50 $\mu \mathrm{M})$ was used as a positive control.

\section{RESULTS and DISCUSSION}

\section{Antioxidant results}

Antioxidant compounds can be classified in several ways. Due to their activity, they can be classified as non-enzymatic and enzymatic antioxidants. These work by destroying and decomposing free radical molecules. Indeed, antioxidant enzymes convert dangerous oxidizing products into multi-stage mechanism and in the presence of manufacturers such as zinc, manganese, copper, and iron into multistage mechanism into water and hydrogen peroxide $\left(\mathrm{H}_{2} \mathrm{O}_{2}\right)$ (Gülçin et al., 2004a). Some examples of non-enzymatic include vitamin $\mathrm{E}$, vitamin $\mathrm{C}$, carotenoids, and glutathione. The cells of the complete aerobic organism in nature have antioxidant defense systems such as antioxidant nutrients to repair or eliminate defective compounds. Antioxidant compounds can protect human cells from radicals and the effects of ROS (Gülçin et al., 2004b). Also, reactive oxygen species (RNS) and ROS can cause DNA 
harm which can alter mutations. Antioxidant compounds are extensively utilized as food additives for protecting food oxidative reduction. ROS agents contain free radicals such as hydroxyl radicals, anion superoxide radicals, and non-radical types such as hydrogen peroxide and single oxygen (Gülçin et al., 2004c). Recently, the interest in studying natural antioxidants due to their use in food or pharmaceuticals to replace synthetic antioxidant compounds, which are limited due to their side effects like carcinogenicity, is of great interest in studying natural antioxidants. In this work, several measurements of various antioxidants based on various reaction processes were utilized to detect the strong antioxidant of the particle.

i. $\quad$ In $\mathrm{Fe}^{3+}\left(\mathrm{CN}^{-}\right)$reduction method 6 , the reducing power of biologically active compounds indicates their electron donor capacity. The $\mathrm{Fe}^{3+}\left(\mathrm{CN}^{-}\right)$reduction method identifies 6 antioxidant effects of each molecule as a reduction in the ability to react (Gülçin, 2008). Quebecol compound had potent reducing activity using $\mathrm{Fe}^{3+}\left(\mathrm{CN}^{-}\right)_{6}$ reduction and with the standards ( $\alpha$-tocopherol, Trolox, BHT, and BHA). It can be observed in Table 1 and Figure 2 that the $\mathrm{Fe}^{3+}$ reducing capacity of Quebecol compound and the standard compounds were: BHA $\left(2.418 \pm 0.022, \mathrm{r}^{2}: 0.9602\right)>$ BHT $\left(1.930 \pm 0.012, \mathrm{r}^{2}: 0.9793\right)>$ Trolox $\left(1.766 \pm 0.013, \mathrm{r}^{2}: 0.9638\right)>\alpha$-Tocopherol $\left(1.512 \pm 0.017, \mathrm{r}^{2}: 0.9424\right)>$ Quebecol $\left(1.164 \pm 0.011, \mathrm{r}^{2}\right.$ : $0.9963)$ at the same concentration $\left(30 \mu \mathrm{g} \mathrm{mL}^{-1}\right)$.

ii. CUPRAC is an affordable, simple, selective, fast, and stable and antioxidant that is useful for a extensive range of polyphenol molecules as well as for thiols, artificial antioxidant compounds (Gülçin et al., 2008). Mineral ions $\left(\mathrm{Cu}^{2+}\right)$ that reduce the strength of 30 micrograms per milliliter of the concentration of the cobblestone compound and the standard reducing agents are shown in Table 1 and Figure 2. Cupric ions $\left(\mathrm{Cu}^{2+}\right)$ reducing capacity of Quebecol compound and standards were: BHA $\left(2.443 \pm 0.027, r^{2}: 0.9834\right)>$ BHT $\left(2.003 \pm 0.004, r^{2}: 0.9966\right)>$ Quebecol $\left(1.354 \pm 0.018, r^{2}: 0.9703\right)>$ Trolox $\left(1.208 \pm 0.005, \mathrm{r}^{2}: 0.9811\right)>\alpha$-Tocopherol $\left(1.059 \pm 0.182, \mathrm{r}^{2}: 0.9072\right)$ at the same concentration $\left(30 \mu \mathrm{g} \mathrm{mL}^{-1}\right)$.

iii. DPPH is based on measuring the ability to reduce antioxidant compounds compared to DPPH radicals (Köksal and Gülçin 2008). Table 2 and Figure 3 show half maximal radical scavenging concentrations $\left(\mathrm{IC}_{50}\right)$ of Quebecol and the reference radical scavenger agents like BHT, Trolox, BHA, and $\alpha$-tocopherol. $\mathrm{IC}_{50}$ values were $8.63 \mu \mathrm{g} \mathrm{mL}^{-1}\left(\mathrm{r}^{2}: 0.9814\right)$ for BHT, $11.03 \mu \mathrm{g} \mathrm{mL}^{-1}\left(\mathrm{r}^{2}: 0.9783\right)$ for BHA, $23.04 \mu \mathrm{g} \mathrm{mL}^{-1}\left(\mathrm{r}^{2}: 0.9966\right)$ for $\alpha$-Tocopherol, $18.24 \mu \mathrm{g} \mathrm{mL}^{-1}\left(\mathrm{r}^{2}: 0.9580\right)$ for Trolox, $14.78 \mu \mathrm{g} \mathrm{mL}^{-}$ ${ }^{1}\left(r^{2}: 0.9812\right)$ for Quebecol.

iv. As with DPPH free radical tracking activity, a lower value of IC50 indicates higher ABTS $^{+}$ activity. Another improved method for determining fine dust is $\mathrm{ABT}^{\circ+}$ activity. ABTS radicals are produced in an $\mathrm{K}_{2} \mathrm{~S}_{2} \mathrm{O}_{8} / \mathrm{ABTS}$ system (Köksal et al., 2009). $\mathrm{IC}_{50}$ values for Quebecol and control agents like trolox, $\alpha$-tocopherol, BHT, and BHA were $5.38 \mu \mathrm{g} \mathrm{mL}^{-1}\left(\mathrm{r}^{2}: 0.9710\right)$ for Quebecol, $4.06 \mu \mathrm{g} \mathrm{mL}^{-1}$ $\left(\mathrm{r}^{2}: 0.9903\right)$ for BHT, $4.61 \mu \mathrm{g} \mathrm{mL} \mathrm{L}^{-1}\left(\mathrm{r}^{2}: 0.9618\right)$ for BHA, $6.80 \mu \mathrm{g} \mathrm{mL} \mathrm{L}^{-1}\left(\mathrm{r}^{2}: 0.9831\right)$ for Trolox, $9.52 \mu \mathrm{g}$ $\mathrm{mL}^{-1}\left(\mathrm{r}^{2}: 0.9682\right)$ for $\alpha$-Tocopherol. (Table 2 and Figure 3$)$. 

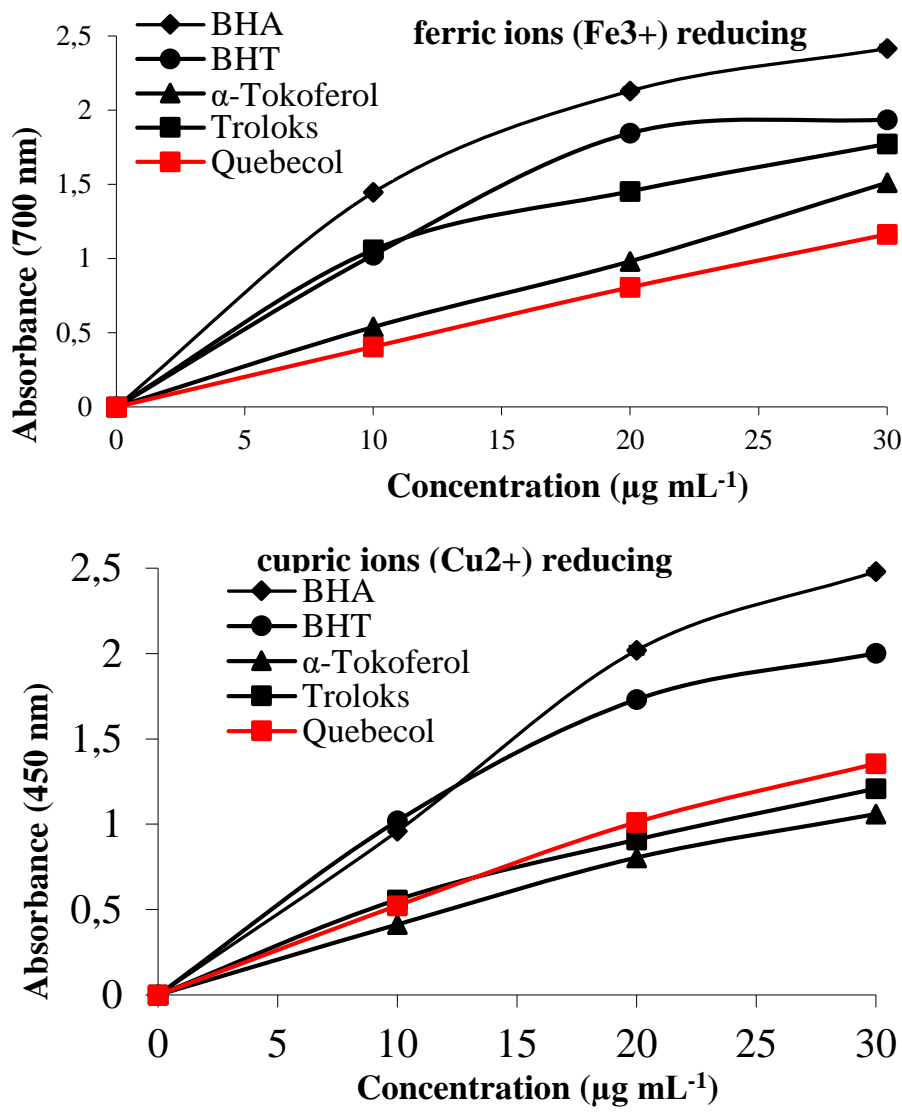

Figure 2. Reducing power graphs of ferric ions $\left(\mathrm{Fe}^{3+}\right)$, and CUPRAK reducing capacity.
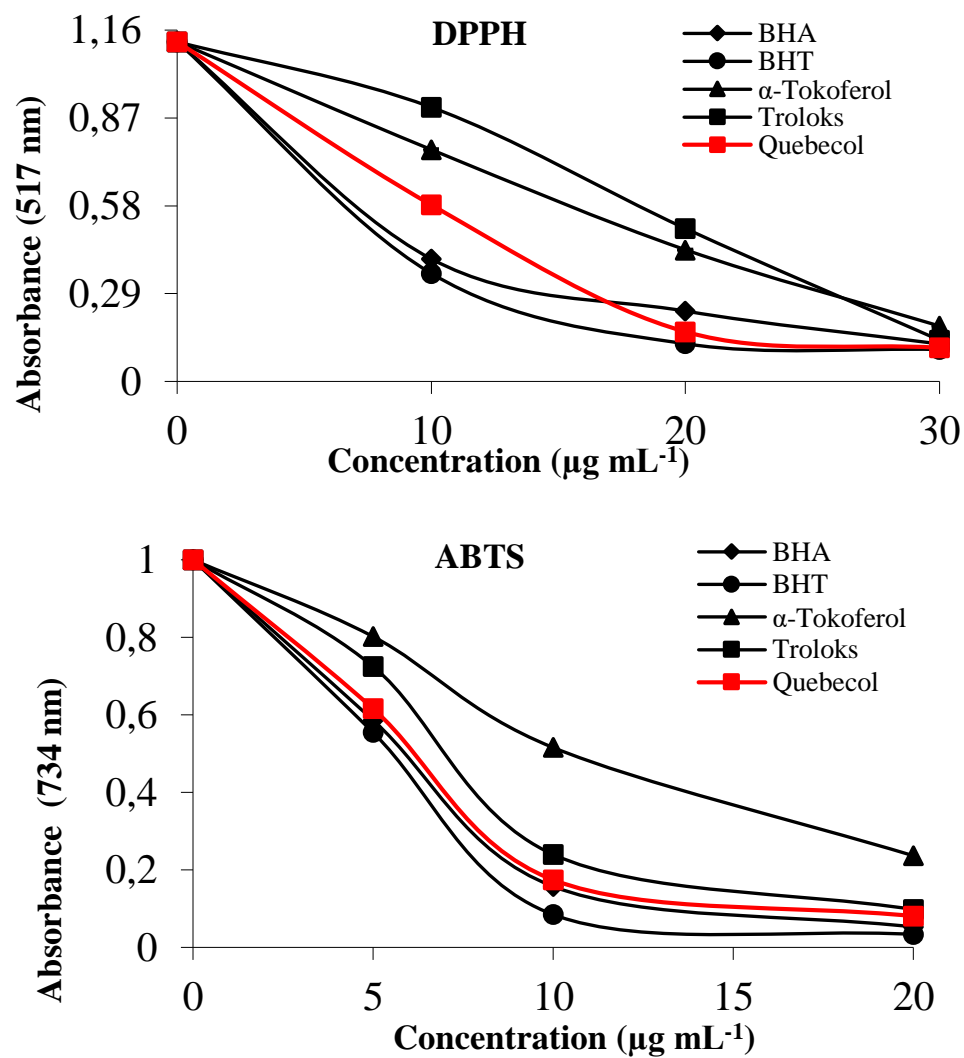

Figure 3. Radical scavenging graphs of DPPH· and $\mathrm{ABTS}^{\cdot+}$ methods. 
Table 1. Determination of reducing power assays.

\begin{tabular}{lllll}
\hline \multirow{2}{*}{ Antioxidants } & \multicolumn{2}{c}{$\mathbf{F e}^{\mathbf{3 +}}-\mathbf{F e}^{\mathbf{2 +}}$ reducing } & \multicolumn{2}{c}{$\mathbf{C u}^{\mathbf{2 +}} \mathbf{- C \mathbf { C u } ^ { + } \text { reducing }}$} \\
\cline { 2 - 5 } & $\boldsymbol{\lambda} \mathbf{7 0 0}$ & $\mathbf{R}^{\mathbf{2}}$ & $\boldsymbol{\lambda} \mathbf{4 5 0}$ & $\mathbf{R}^{\mathbf{2}}$ \\
\hline BHA & $2.41 \pm 0.025$ & 0.9602 & $2.443 \pm 0.027$ & 0.9834 \\
BHT & $1.930 \pm 0.011$ & 0.9793 & $2.001 \pm 0.002$ & 0.9966 \\
$\boldsymbol{\alpha}$-Tocopherol & $1.510 \pm 0.015$ & 0.9424 & $1.059 \pm 0.182$ & 0.9072 \\
Trolox & $1.766 \pm 0.013$ & 0.9638 & $1.208 \pm 0.003$ & 0.9811 \\
Quebecol & $1.164 \pm 0.011$ & 0.9963 & $1.354 \pm 0.018$ & 0.9703 \\
\hline
\end{tabular}

Table 2. Determination of $\mathrm{IC}_{50}$ amounts of natural compound and standards for radical scavenging $\mathrm{DPPH} \cdot$ and $\mathrm{ABTS}^{*+}$.

\begin{tabular}{lcccc}
\hline Antioxidant Compounds & DPPH· scavenging & $\mathbf{R}^{\mathbf{2}}$ & ABTS $^{\bullet+}$ scavenging & $\mathbf{R}^{\mathbf{2}}$ \\
\hline BHA & 11.03 & 0.9783 & 4.61 & 0.9618 \\
BHT & 8.63 & 0.9814 & 4.06 & 0.9903 \\
o-Tocopherol & 23.04 & 0.9966 & 9.52 & 0.9682 \\
Trolox & 18.24 & 0.9580 & 6.80 & 0.9831 \\
Quebecol & 14.78 & 0.9812 & 5.38 & 0.9710 \\
\hline
\end{tabular}

\section{Enzyme results}

Tyrosinase inhibitor compounds are utilized to therapy of hyperpigmentation diseases, skin whitening, and age spots, whereas tyrosinase activator compounds cause the enhance of melanogenesis that can protect the skin from UV harm (Wang et al., 2014). For tyrosinase enzyme, Quebecol and kojic Acid (Standard) as natural phenols have $\mathrm{IC}_{50}$ values of 4.64 and $9.28 \mu \mathrm{M}$ (Table 1). For tyrosinase, $\mathrm{IC}_{50}$ amounts of kojic acid as positive control and Quebecol the following order: Quebecol $\left(4.64 \mu \mathrm{M}, \mathrm{r}^{2}\right.$ : $0.9219)<$ kojic acid $\left(9.28 \mu \mathrm{M}, \mathrm{r}^{2}: 0.9889\right)$. In addition to treating pigment disorders, tyrosinase inhibitors are also used to control insects and the food industry. Additionally, the tyrosinase enzyme has important roles in the developmental and defense functions of insects. Involved in sclerotization in insects, wound healing, melanogenesis, and parasite encapsulation. The importance and development of tyrosinase inhibitors have become an alternative method of pest control. Indeed, In the food, tyrosinase is crucial in controlling the economics and quality of vegetables and fruits (Hung et al., 2006; Chen et al., 2017).

Table 3. Tyrosinase inhibitory results of a natural compound

\begin{tabular}{lcc}
\hline Natural Compounds & \multicolumn{2}{c}{ Tyrosinase Enzyme } \\
\cline { 2 - 3 } & IC50 $(\boldsymbol{\mu M})$ & $\mathbf{R}^{\mathbf{2}}$ \\
\hline Quebecol & $4.64 \pm 0.62$ & 0.9219 \\
Kojic acid (as Standard) & $9.28 \pm 1.15$ & 0.9889 \\
\hline
\end{tabular}

\section{CONCLUSIONS}

The decrease of DNA damage, chronic diseases, mutagenesis, growth, inhibition of pathogenic bacterial is mostly associated with the termination of radical molecules propagation in biochemical systems. The antioxidant potential is widely used as a feature for medicinal components. In this research, the antioxidant activity of Quebecol was compared to BHT, BHA, $\alpha$-tocopherol, and Trolox. Quebecol as tyrosinase inhibitor compound can be attractive in medicinal industries and cosmetics as 
depigmentation factors and also in agriculture and food industries as antibrowning molecule. Natural product compounds from animals, microbes, plants, and minerals have long been a traditional source for the therapy of human diseases. In the past decades, the study on natural product compounds for the pharmaceutical industry had reduced due to multiple challenges.

\section{Conflict of interest statement}

The author is no conflicts of interest.

\section{REFERENCES}

Apak R, Güçlü K, Demirata B, Özyürek M, Esin Çelik S, Bektaşoğlu B, Işı1 Berker K, Özyurt D. 2007. Comparative evaluation of various total antioxidant capacity assays applied to phenolic compounds with the CUPRAC assay. Molecules, 12: 1496-1547.

Ball DW. 2007. The Chemical Composition of Maple Syrup. J. Chem. Edu. 84: 1647

Chen J, Liu S, Huang Z, Huang W, Li Q, Ye Y. 2017. Molecular inhibitory mechanism of dihydromyricetin on mushroom tyrosinase. Journal of Biomolecular Structure and Dynamics. 113

Elmastaş M, Gülçin İ, Beydemir Ş, Küfrevioğlu Öİ, Aboul-Enein HY. 2006. Radical scavenging activity and antioxidant capacity of bay leaf extracts. Analytical Letters, 39: 47-65.

Elmastaş M, Gülçin İ, Öztürk L, Gökçe İ. 2005. Investigation of antioxidant properties of spearmint (Mentha spicata L.). Asian Journal of Chemistry, 17: 137-148.

Espín J.C, and Wichers HJ. 1999. Slow-binding inhibition of mushroom (Agaricus bisporus) tyrosinase isoforms by tropolone. Journal of Agricultural and Food Chemistry, 47 (7): 2638-2644.

Gülçin İ, 2005. The antioxidant and radical scavenging activities of black pepper (Piper nigrum) seeds. International Journal of Food Sciences and Nutrition, 56: 491-499.

Gülçin İ, Berashvili D, Gepdiremen A. 2005a. Antiradical and antioxidant activity of total anthocyanins from Perilla pankinensis decne. Journal of Ethnopharmacology, 101: 287-293.

Gülçin İ, Beydemir Ş, Alici HA, Elmastaş M, Büyükokuroğlu ME, 2004a. In vitro antioxidant properties of morphine. Pharmacological Research, 49: 59-66.

Gülçin İ, Beydemir Ş, Hisar O. 2005b. The effect of $\alpha$-tocopherol on the antioxidant enzymes activities and lipid peroxidation of rainbow trout (Oncorhynchus mykiss), Acta Veterinaria Hungarica, 53: 425-433.

Gülçin İ, Beydemir Ş, Şat İG, Küfrevioğlu Öİ. 2005c. Evaluation of antioxidant activity of cornelian cherry (Cornus mas L.). Acta Aliment Hung. 34: 193-202.

Gülçin I, Elias R, Gepdiremen A, Boyer L. 2006a. Antioxidant activity of lignans from fringe tree (Chionanthus virginicus L.). European Food Research. 223: 759-767.

Gülçin İ, Küfrevioğlu Öİ, Oktay M, Büyükokuroğlu ME, 2004b. Antioxidant, antimicrobial, antiulcer and analgesic activities of nettle (Urtica dioica L.). Journal of Ethnopharmacology, 90: 205-215.

Gülçin İ, Mshvildadze V, Gepdiremen A, Elias R. 2006b. Screening of antiradical and antioxidant activity of monodesmosides and crude extract from Leontice smirnowii tuber. Phytomedicine, 13: 343-351.

Gülçin İ, Şat İG, Beydemir Ş, Küfrevioğlu Öİ, 2004c. Evaluation of the in vitro antioxidant properties of extracts of broccoli (Brassica oleracea L.). Italian Journal of Food Sciences, 16 (1): 17-30.

Gülçin İ, Tel AZ, Kirecci E. 2008. Antioxidant, antimicrobial, antifungal and antiradical activities of Cyclotrichium niveum (Boiss.) Manden and Scheng. International Journal of Food Properties, 11: 450-471. 
Gülçin İ. 2006. Antioxidant and Antiradical Activities of L-Carnitine. Life Sciences, 78: 803-811.

Gülçin İ. 2006. Antioxidant activity of caffeic acid (3,4-dihydroxycinnamic acid). Toxicology, 217: 213220.

Gülçin İ. 2008. Measurement of antioxidant ability of melatonin and serotonin by the DMPD and CUPRAC methods as trolox equivalent. Journal of Enzyme Inhibition and Medicinal Chemistry, 23: 871-876.

Huang XH, Chen QX, Wang Q, Song KK, Wang J, Sha L, Guan X. 2006. Inhibition of the activity of mushroom tyrosinase by alkylbenzoic acids Food Chemistry, 94: 1-6

Ishioka W, Oonuki S, Iwadate T, Nihei K. 2019. Resorcinol alkyl glucosides as potent tyrosinase inhibitors. Bioorganic \& Medicinal Chemistry Letters, 29(2): 313-316.

Köksal E, Gülçin İ, Öztürk Sarıkaya SB, Bursal E. 2009. On the in vitro antioxidant activity of silymarin. Journal of Enzyme Inhibition and Medicinal Chemistry, 24: 395-405.

Köksal E, Gülçin İ. 2008. Antioxidant activity of cauliflower (Brassica oleracea L.). Turkish Journal of Agriculture and Forestry, 32: 65-78.

Li L, Seeram NP. 2011. Quebecol, a novel phenolic compound isolated from Canadian maple syrup. Journal of Functional Foods. 3: 125-128.

Matsumoto T, Nakajima T, Iwadate T, Nihei K. 2018. Chemical synthesis and tyrosinase-inhibitory activity of isotachioside and its related glycosides. Carbohydrate Research, 465: 22-28.

Re R, Pellegrini N, Proteggente A, Pannala A, Yang M, Rice-Evans C. 1999. Antioxidant activity applying an improved ABTS radical cation decolorization assay. 26: 1231-1237.

Ros JR, Rodríguez-López JN, García-Cánovas F. 1993. Effect of L-ascorbic acid on the monophenolase activity of tyrosinase. Biochemistry Journal, 295: 309-312

Tanaka Y, Suzuki M, Kodachi Y, Nihei K. 2019. Molecular design of potent, hydrophilic tyrosinase inhibitors based on the natural dihydrooxyresveratrol skeleton. Carbohydrate Research, 472: 4249.

Wang T, Zhang G, Yan J, Gong D. 2014. Inhibitory effect of morin on tyrosinase: insights from spectroscopic and molecular docking studies. Food Chemistry., 163: 226-233

Zolghadri S, Bahrami A, Hassan Khan MT, Munoz-Munoz J, Garcia-Molina F, Garcia-Canovas F, Saboury AA. 2019. A comprehensive review on tyrosinase inhibitors. Journal of Enzyme Inhibition and Medicinal Chemistry, 34 (1): 279-309. 